\title{
New Insights in Anti-Angiogenesis in Multiple Myeloma
}

\author{
Domenico Ribatti ${ }^{1, *}$ (i) and Angelo Vacca ${ }^{2, *}$ \\ 1 Department of Basic Medical Sciences, Neurosciences and Sensory Organs, University of Bari Medical \\ School, Bari 70124, Italy \\ 2 Department of Biomedical Sciences, and Human Oncology, Section of Internal Medicine and Clinical \\ Oncology, University of Bari Medical School, Bari 70124, Italy \\ * Correspondence: domenico.ribatti@uniba.it (D.R.); angelo.vacca@uniba.it (A.V.); Tel.: +39-080-547-8326 \\ (D.R.); +39-080-547-8895 (A.V.)
}

Received: 19 June 2018; Accepted: 10 July 2018; Published: 12 July 2018

\begin{abstract}
Angiogenesis is a constant hallmark of multiple myeloma (MM) progression and involves direct production of angiogenic cytokines by plasma cells and their induction within the bone marrow microenvironment. This article summarizes the more recent literature data concerning the employment of anti-angiogenic therapeutic agents actually used in preclinical models and clinical settings for the treatment of multiple myeloma.
\end{abstract}

Keywords: angiogenesis; anti-angiogenesis; multiple myeloma; tumor growth

\section{Angiogenesis in Multiple Myeloma (MM)}

Under physiological conditions, angiogenesis depends on the balance of positive and negative angiogenic modulators within the vascular microenvironment. Tumor angiogenesis is linked to switch this balance, and mainly depends on the release by neoplastic cells of growth factors specific for endothelial cells and able to stimulate the growth of the host's blood vessels [1]. Numerous clinical studies have shown that the degree of angiogenesis or the levels of angiogenic factors are correlated with disease stage, prognosis or response to therapy, suggesting that angiogenesis induction in solid and hematological tumors has a pathophysiologic relevance for disease progression.

Solid tumors progress through an avascular phase (dormant tumor) followed by a vascular phase (angiogenic switch). The role of angiogenesis in the growth of hematological malignancies has become evident since 1994 [2] through the demonstration that tumor progression related to the degree of angiogenesis. Tumor angiogenesis occur through different mechanisms: (i) postnatal vasculogenesis [3]; (ii) vasculogenic mimicry [4]; (iii) vascular cooption [5]; (iv) intussusceptions [6].

Tumor blood vessels, consisting of consist of endothelial cells, mural cells and their enveloping basement membrane, present structural and functional abnormalities. Their leakiness and expression of specific surface molecules facilitates metastatic process.

Angiogenesis is a feature of MM progression through the transition from monoclonal gammopathies of undetermined significance (MGUS) to MM, and has a prognostic potential [7]. It is induced by plasma cells via angiogenic factors released by the cells composing the tumor microenvironment and loss of angiostatic activity in MGUS [8]. It is important to note that already normal plasma cells express a surplus of pro-angiogenic over anti-angiogenic genes which transmits into the ability to induce in vitro angiogenesis. This angiogenic stimulus is further increased in myeloma due to the aberrant expression of pro-angiogenic and down-regulation of anti-angiogenic genes by myeloma cells [9]. 
Rajkumar et al. [10] confirmed in a cohort of 400 patients that a progressive increase in bone marrow microvascular density occurs across the whole spectrum of plasma cell disorders, including primary amyloidosis, MGUS, smouldering and active MM. Several other reports have described a significant correlation between bone marrow (BM) microvascular density and progression free survival (PFS) and overall survival (OS) in MM patients [11]. Moreover, BM microvascular density decreases significantly in patients achieving a remission, but not in patients who had no response to therapy [12].

Within the bone marrow microenvironment, bone marrow stromal cells (BMSCs), hematopoietic stem cells (HSCs), fibroblasts, osteoblasts/osteoclasts, adipocytes, endothelial precursor cells (EPCs), $\mathrm{T}$ lymphocytes, macrophages, and mast cells, increase the concentration of angiogenic factors and matrix degrading enzymes in the bone marrow microenvironment by direct secretion or following stimulation by myeloma cells or by endothelial cells through paracrine interactions $[13,14]$. BMSCs, osteoclasts, osteoblasts and endothelial cells secrete several factors (Table 1), including vascular endothelial growth factor (VEGF), fibroblast growth factor-2 (FGF-2), tumor necrosis factor alpha (TNF- $\alpha$ ), hepatocyte growth factor (HGF), interleukin-6 and -8 (IL-6 and IL-8), osteopontin (OPN), angiopoietin-1 (Ang-1), B-cell activating factor, stromal cell-derived factor $1 \alpha$ (SDF1- $\alpha$, also known as CXCL12), and various Notch family members, which are further up-regulated by tumor cell adhesion to extracellular matrix proteins and/or BMSCs $[13,14]$. Macrophages, mast cells and fibroblasts contribute to angiogenesis in MM, in parallel to tumor progression [15-17].

Table 1. Main angiogenic factors in active multiple myeloma (MM) [18].

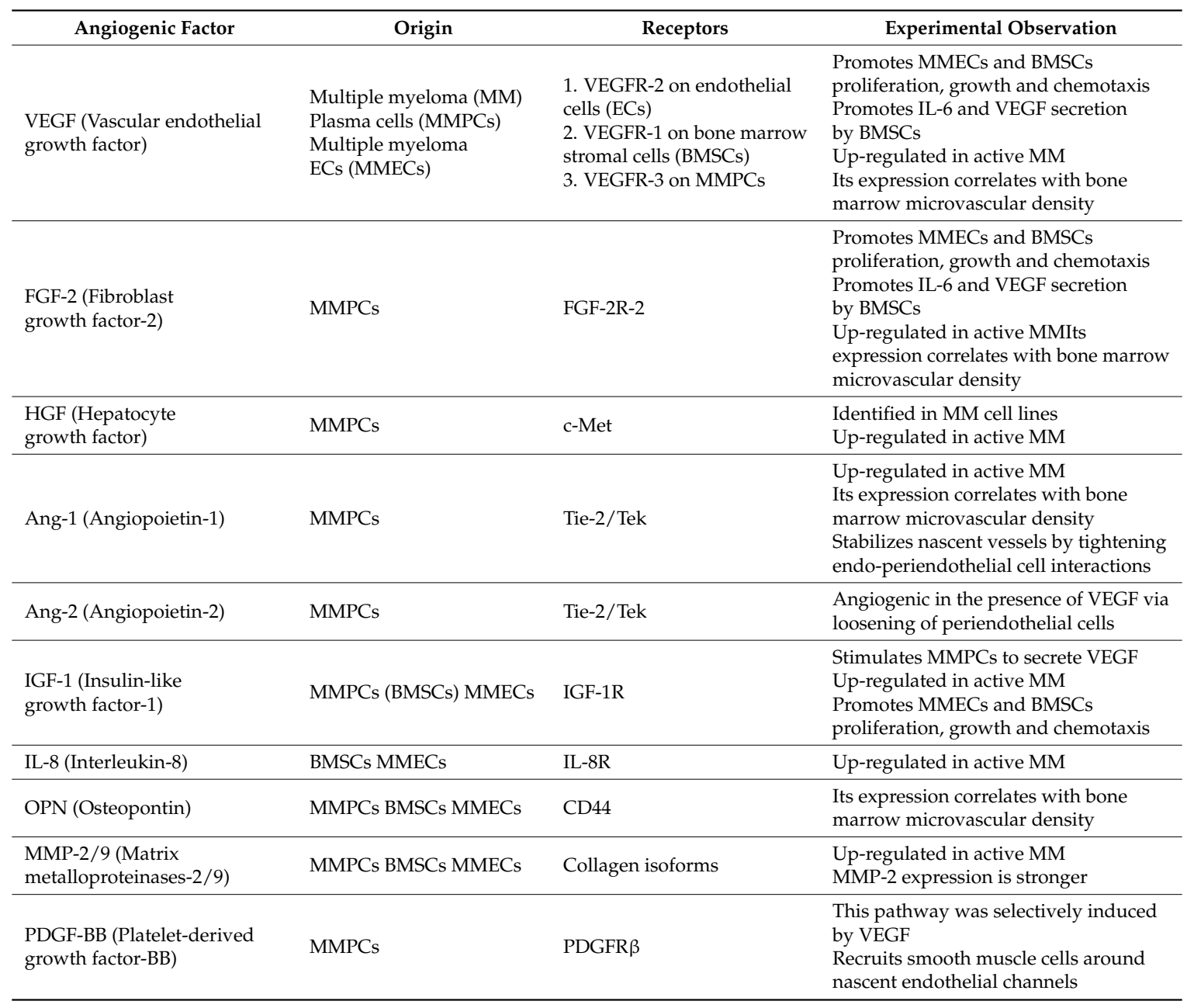


Table 1. Cont.

\begin{tabular}{llll}
\hline \multicolumn{1}{c}{ Angiogenic Factor } & \multicolumn{1}{c}{ Origin } & Receptors & Experimental Observation \\
\hline ADM (Adrenomedullin) & MMPCs & ADMR & Induces in vitro angiogenesis \\
\hline $\begin{array}{l}\text { TNF- } \alpha \text { (Tumor necrosis } \\
\text { factor- } \alpha)\end{array}$ & MMPCs BMSCs MMECs & TNF- $\alpha$ R & $\begin{array}{l}\text { Stimulation of IL-6 secretion, } \\
\text { bone resorption and expression of } \\
\text { adhesion molecules }\end{array}$ \\
\hline $\begin{array}{l}\text { TGF- } \beta 1 \text { (Transforming growth } \\
\text { factor- } \beta 1)\end{array}$ & MMPCs BMSCs MMECs & TGF- $\beta 1 \mathrm{R}$ & $\begin{array}{l}\text { Stabilizes nascent vessels by stimulating } \\
\text { ECM production }\end{array}$ \\
\hline $\begin{array}{l}\text { CXCL8/IL8 (CXC-chemokine } \\
\text { CXCl8/IL8) }\end{array}$ & MMECs & CXCR2 & Takes part in a paracrine loop between \\
\hline $\begin{array}{l}\text { CXCL11/I-TAC } \\
\text { CXCL11-interferon-inducible } \\
\text { T-cell } \alpha \text { chemoattractant) }\end{array}$ & MMECs & CXCR3 & MMPCs proliferation and chemotaxis \\
\hline $\begin{array}{l}\text { CXCL12/SDF-1 } \alpha \\
\text { (CXCL12/stromal } \\
\text { cell-derived factor-1 } \alpha)\end{array}$ & MMECs & Takes part in a paracrine loop between \\
\hline
\end{tabular}

In active MM plasma cells secrete VEGF and FGF-2 that induce the cells of the tumor microenvironment to secrete their own VEGF, FGF-2, and HGF, able to recruit and activate the $\mathrm{MM}$-associated macrophages [8]. Moreover, bone marrow macrophages protect MM cells from spontaneous and melphalan-induced apoptosis [19]. In patients with active MM, FACS analysis on isolated bone marrow mononuclear cells revealed higher percentages of CD68+ macrophages than in patients with non-active disease or those with MGUS [10]. Bone marrow macrophages in patients with active MM were similar to paired endothelial cells and contributed to umor angiogenesis through a vasculogenic mimicry [10]. When exposed in vitro to VEGF and FGF-2, tumor macrophages differentiated into cells similar to $\mathrm{MM}$ endothelial cells, able to generate in vitro capillary-like networks [10]. Moreover, at confocal laser microscopy tumor macrophages expressed markers of both macrophages and endothelial cells [10].

Bone marrow angiogenesis and mast cell counts are highly correlated in patients with non-active and active MM and in those with MGUS, and both parameters increase simultaneously in active MM [20]. At the ultrastructural level, vessels are lined by mast cells showing numerous and irregularly shaped electron dense granules [9]. Moreover, thick endothelial cells, containing endocytic vesicles, but lacking granules, were connected by a junctional system with the mast cells lining the vessel wall [9]. These ultrastructural findings have been confirmed by confocal laser microscopy using double anti-tryptase (to mark mast cells) and anti-FVIII-RA (to mark endothelial cells) antibodies. In MM, vessels displayed characteristics of both mast cells and endothelial cells, while in MGUS, the vessels were uniformly stained with the endothelial marker [9]. Overall, these data suggest that mast cells also contribute to MM neovascularization.

Tumor-associated fibroblasts (TAFs) were increased in patients with active MM compared to those in remission and those with MGUS. The cells displayed an activated phenotype, and produced high levels of TGF- $\beta$, IL-6, SDF- $1 \alpha$, and IGF-1 [15]. Moreover, TAFs showed a heterogeneous phenotype which entailed their origin from resident fibroblasts, and from endothelial cells and HSCs via endothelial-mesenchymal transition, and from mesenchymal stem cells (MSCs) via mesenchymal transition, all induced by both tumor-associated fibroblasts and MM plasma cells. Active MM fibroblasts induces chemotaxis, adhesion, proliferation and apoptosis-resistance of MM cells through the release of cytokines and cell-to-cell contact that was inhibited by blocking CXCR4, $\beta 3$ and $\beta 7$ integrins, and fibronectin. Experiments performed in syngeneic 5T33MM and xenografted mouse models showed that MM cells induced the tumor fibroblasts recruitment and expansion which, in turn, favored tumor initiation and progression as well as angiogenesis [15].

Circulating endothelial cells and endothelial precursor cells (EPCs) contribute to the neovascularization, and the presence of EPCs suggests that vasculogenesis may also contribute to the full MM vascular tree [14]. We have demonstrated that in patients with active MM, plasma cells and 
stromal cells in the bone marrow microenvironment recruit HSCs, and induce their transformation into mature MM endothelial cells [21]. In fact, when HSCs of MM patients were incubated with VEGF, FGF-2 and insulin-like growth factor (IGF), cells differentiate into endothelial cell-like cells expressing typical endothelial markers, such as factor VIII-related antigen (FVIII-RA), VEGFR-2 and VE-cadherin, and form capillary-like networks in vitro [21].

The deregulated interactions between MM cells and other cells of the microenvironment are at the basis of the clinical manifestations of the disease, including osteolytic bone lesions, hypercalcemia, and suppressed haematopoietic functions. The vascular niche is comprised of vasculature forming a conduit which enables MM cells both to leave the osteoblastic niche and enter the vascular system via transendothelial migration, hence to return to the bone marrow via homing mechanisms. In this context, endothelial cells, pericytes, and smooth muscle cells create a microenvironment that recruits EPCs, MSCs and HSCs. The vascular niche is a site required for the differentiation and maturation of HSCs via both the production and secretion of various cytokines and growth factors, as well as via direct cell-cell contact. HSCs in turn prolong survival of bone marrow endothelial cells by secreting endothelial cell growth factors [22].

A comparative gene expression profiling of endothelial cells derived from patients with MM and with MGUS has been carried out [23]. Twenty-two genes were found differentially expressed (14 down-regulated and 8 up-regulated) at relatively high stringency in MM endothelial cells. Deregulated genes were mostly involved in extracellular matrix formation and bone remodeling, cell adhesion, chemotaxis/spread, angiogenesis, resistance to apoptosis, and cell-cycle regulation. Validation was focused on DIRAS3, SERPINF1, SRPX, BNIP3, IER3, and SEPW1 genes, which were not previously found to be functionally correlated to the angiogenic phenotype of MM endothelial cells. The siRNA for three up-regulated genes (BNIP3, IER3, and SEPW1) affected endothelial cell proliferation, apoptosis, adhesion/spread, and capillary tube formation. Two apoptosis-related genes were up-regulated in MM endothelial cells: BNIP3 belongs to the Bcl-2 family, and IER3 is a member of the "immediate early response gene" family induced by the anti-apoptotic factor nuclear factor $\mathrm{KB}$ in response to the tumor necrosis factor- $\alpha$ and ligand-mediated FAS. Coordinated anti-apoptotic mechanisms are activated in MM endothelial cells and contribute to their over-angiogenic phenotype.

Recombinant human erythropoietin ( $\mathrm{rHuEpo}$ ) is involved in the regulation of the angiogenic response in $\mathrm{MM}$ through a direct effect on macrophages and endothelial cells isolated from the bone marrow of patients with MM [24,25]. Interactions between plasma cells and BMSCs are modulated by specific cytokines, receptors and adhesion molecules, responsible for the proliferation, migration and survival of plasma cells, disease progression and acquisition of drug resistance [13]. Although it has well established that myeloma cells drive angiogenesis by the secretion of angiogenic factors, there is also evidence for a loss of anti-angiogenic activity on the part of bone marrow plasma cells with disease progression $[12,26]$.

\section{Anti-Angiogenesis in Multiple Myeloma}

A number of antiangiogenic therapeutic strategies have been evaluated in myeloma with varying degrees of efficacy but the results overall further confirm the role of angiogenesisin the pathogenesis of myeloma. In MM treatment, thalidomide, lenalidomide and bortezomib have changed clinical practice for both the newly presented and the relapsed patients.

\subsection{Thalidomide}

The anti-angiogenic properties of thalidomide led to the consideration of its use in MM [27]. In addition to its anti-angiogenic activity due to its inhibition of secretion of VEGF and IL-6 [28], thalidomide enhances T cell- and NK cell-mediated immunological responses, induces caspase- 8 mediated apoptosis, and down-regulates IL-6 production within the BM microenvironment [29,30]. Based on the increasing interest for the use of thalidomide as an anti-angiogenic agent, Barlogie and colleagues initiated a compassionate-use trial of "anti-angiogenic therapy." Barlogie conducted a trial 
including 84 patients and had $32 \%$ of patients respond, making it the first new drug with single-agent activity for myeloma in more than three decades [31].

\subsection{Immunomodulatory Drugs}

Subsequently to thalidomide, a series of immounomodulatory drugs (IMiDs) have been developed. Pomalidomide is the most potent IMiD, having 100 times the strength of thalidomide and 10 times that of lenalidomide [32].

Lenalidomide inhibits VEGF-induced PI3K-Akt pathway signaling and HIF-1 $\alpha$ expression [32], exerts an anti-tumor necrosis factor alpha (TNF $\alpha$ ) activity, modulates the immune response stimulating $\mathrm{T}$ cells and NK cells activities, induces apoptosis of tumor cells, and decreases the binding of MM cells to BMSCs [30,33-36]. Moreover, lenalidomide alter the balance of bone resorption by inhibiting osteoclast formation [37,38]. Lenalidomide inhibits MM plasma cells-induced angiogenesis in vivo in the chorioallantoic membrane (CAM) assay and endothelial cells-induced angiogenesis in vitro in the Matrigel assay, inhibits MM endothelial cell migration, and down-regulates key genes and proteins related to MM angiogenesis [39]. In clinical trials with lenalidomide, the absence of a significant reduction in bone marrow neovascularization after treatment suggests that the anti-angiogenic effect may not play a major role in this setting [40].

Lenalidomide can be taken orally, produced only modest side effects, and was an important addition to the treatment for multiple myeloma. Lenalidomide was approved in the USA in 2006 for the treatment of relapse refractory multiple myeloma (RRMM) [41]. When it was combined with dexamethasone $90 \%$ of newly diagnosed patients responded [42]. A retrospective analysis of clinical trials demonstrated an higher overall response rate (ORR), longer time to progression (TTP), and progression-free survival (PFS) for patients treated with lenalidomide and dexamethasone, compared to the those treated only with dexamethasone [43]. Lenalidomide sensitizes MM plasma cells to bortezomib [44], and lenalidomide/bortezomib/dexamethasone produced responses in $84 \%$ of relapsed/refractory patients, including complete response or near complete response in $21 \%$ [45], and produced responses in $98-100 \%$ of newly diagnosed MM patients [46]. Lenalidomide is partly eliminated in urine and it is therefore necessary to adjust the dose depending on renal function.

Pomalinomide is active against MM cell lines in case of bortezomib and lenalidomide resistance and inhibits angiogenesis by targeting VEGF and HIF-1 $\alpha$ [47]. Pomalidomide is effective in RRMM patients both as a single agent $[46,48,49]$ and in combination with low-dose dexamethasone, even in patients refractory to other IMiDs and/or bortezomib [41,50-52]. Comparison of pomalidomide plus low-dexamethasone to high-dose dexamethasone demonstrated a longer PFS and a better response rate in the pomalidomide group [53]. The pharmacokinetics of pomalidomide does not seem to be affected by renal impairment.

\subsection{Bortezomib and Second-Generation Proteasome Inhibitors}

Bortezomib is currently used in the treatment of myeloma and in addition to its proteosomal inhibitory effects it exerts inhibitory effects on endothelial cell proliferation and migration as well as to downregulate VEGF and Ang expression by endothelial cells. Bortezomib induces endothelial cell apoptosis [54], inhibits VEGF, IL-6, Ang-1 and Ang-2 and IGF-1 secretion in BMSCs and endothelial cells derived from MM patients [55,56]. Bortezomib is approved for the treatment of MM in the relapsed setting post-transplant or as a second line treatment in patients unsuitable for transplantation. Due to its novel mechanism of action, bortezomib has been shown to induce responses in previously refractory patients (including those with poor risk cytogenetics), and results in an increased progression free and overall survival in relapsed patients when compared with dexamethasone treatment alone. It is well tolerated and peripheral neuropathy is the most common dose limiting toxicity and thrombocytopenia can generally be managed with platelet transfusions. Bortezomib shows a synergistic effect in combination with dexamethasone and also sensitizes myeloma cells to the effects of other chemotherapeutic agents [57]. Carfilzomib is a second-generation proteasome inhibitor 
with a similar anti-angiogenic potential like bortezomib. Carfilzomib binds selectively with the chymotrypsin-like site of the proteolytic core and is currently examined in different doses and regimens in RRMM as in newly diagnosed MM [58]. Inducing irreversible proteasome inhibition, carfilzomib not only demonstrates greater preclinical antitumor activity [59], but it is also effective in cell lines already resistant to bortezomib [59]. Ixazomib is another reversible second-generation proteasome inhibitor that is active in bortezomib-resistant myeloma cells, despite structural similarities [60]. It has become the first orally bioavailable proteasome inhibitor to be approved for the treatment of recurrent multiple myeloma in the USA [59].

\subsection{Bishosphonates}

The administration of bisphosphonates, inhibitors of osteoclasts activity, exerts an antiangiogenic activity. Therapeutic doses of zoledronic acid markedly inhibit in vitro proliferation, chemotaxis and angiogenesis of MM endothelial cells and in vivo angiogenesis in the CAM assay [61]. Bortezomib and zoledronic acid display distinct and synergistic activities on bone marrow macrophages in $\mathrm{MM}$ patients, inhibiting macrophage proliferation, adhesion, migration, and expression of angiogenic cytokines, angiogenesis on Matrigel, VEGFR-2 and ERK1/2 phospho-activation as well as nuclear factor $\mathrm{kB}(\mathrm{NF}-\mathrm{kB})$ [62]. These drugs synergistically inhibit macrophage vasculogenesis on the Matrigel surface and the expression of FVIII-RA, Tie2/Tek, and VEGFR-2/VE-cadherin, expression of cell transdifferentiation into endothelial-like cells. Both drugs reduce phospho-activation of VEGFR-2 and ERK1/2 and NFKB activity [62]. These data provide evidence that the exposure of bone marrow macrophages during the treatment with bortezomib and zoledronic acid impacts their angiogenic and vasculogenic properties, suggesting that these cells may be considered as a target of both drugs in MM patients, demonstrating that when macrophages pre-treated with bortezomib were co-cultured with MM cell lines, the proliferative index of these latter decreased significantly [63].

\section{New Insights}

In a xenograft MM mouse model, the administration of Pazopanib, an orally available inhibitor of VEGFR-1, VEGFR-2, and VEGFR-3 led to higher survival, reduced tumor growth, and angiogenesis. However, the tumors regrew after the treatment ceased [64]. Futhermore, Pazopanib was ineffective in a phase II clinical trial with patients with relapsed and refractory MM [65].

IL-12 receptor B2 (IL-12Rß2) is expressed in primary MM cells but down-regulated compared with normal polyclonal plasmablastic cells and plasma cells [66]. Moreover, IL-12 reduced the pro-angiogenic activity of primary MM cells in vitro and decreased significantly the tumorigenicity of NCI-H929 cell line in SCID/NOD mice by inhibiting cell proliferation and angiogenesis [66].

Coluccia et al. [67] demonstrated that platelet derived growth factor (PDGF)-BB/PDGF receptor beta (PDGFR $\beta$ ) promoted the transcription of MMEC-proangiogenic factors, such as VEGF, FGF-2, and IL-8. Moreover, a prolonged exposure of MM endothelial cells to dasatinib, an oral bioactive PDGFR $\beta$ /Src tyrosine kinase inhibitor, annulled their ability to respond to VEGF, preventing the expression of endogenous VEGF in a time-dependent manner, and the levels of secreted VEGF in the conditioned medium of MM endothelial cells in a dose-dependent manner.

Roccaro et al. [68] demonstrated that microRNA-15a/-16, which are downregulated in MM plasma cells as compared to normal cells, exert an antiangiogenic activity, reducing VEGF secretion from MM cells at the protein level, thereby reducing MM plasma cell proangiogenic activity on endothelial cells and these data were further confirmed in vivo in the CAM assay. Therefore, the antiangiogenic role of microRNA-15a and -16 may contribute, at least in part, to their anti-MM activityTargeting the SDF1- $\alpha / C X C R 4$ pathway with CXCR4 antagonist AMD3100 can mobilize MM cells in the circulation and render them sensitive to anti-myeloma treatment [69]. The combination of ADM3100 with bortezomib led to a decrease in tumor burden in vivo [69]. Ulocuplumab, a monoclonal anti-CXCL4 antibody, as well as neutralization of SDF1 by Olaptesed-pegol (PEGylated mirror-image 1-oligonucleotide), inhibit myeloma cell dissemination and suppress the CXCR4-driven EMT-like [70]. 
Sorafenib, a multi-targeted receptor tyrosine kinase inhibitor, targeting VEGFR-2, VEGFR-3, RAF, PDGFR-B, Flt-3, and cKit exerts a significant anti-MM activity and synergize with other anti-MM drugs [71]. Sorafenib has also been tested in patients with refractory or recurrent MM and was effective in two patients who achieved a partial response and a continuous stable disease [72]. Natalizumab, a selective adhesion molecule inhibitor, which binds $\alpha 4$ integrins inhibits VEGF secretion and angiogenesis and enhances the anti-MM activity of bortezomib and dexamethasone [73]. Akt pathway is crucial for MM survival and drug resistance and has been proposed as a target for future molecular therapies [74].

HGF/cMET enhances the expression of VEGF/VEGFR-2 in MM endothelial cells [75,76] . In vitro and in vivo studies of a selective cMET inhibitor, SU 11274, alone or in combination with bortezomib, lenalidomide and dexamethasone, indicate that the HGF/cMET pathway is a new therapeutic target for RRMM [75,76]. Umezu et al. [77] found that exosomal miR-340 derived from BMSCs inhibited myeloma related angiogenesis via the HGF/cMET signaling pathway in endothelial cells. The use of anti-murine VEGFR-2 antibody DC101 prevented the mobilization of EPCs and delayed tumor progression in the early stages of MM, but was ineffective when used during MM [78]. Clinical trials using DARPin MPO250 in RRMM are already running (e.g., NCT03136653) and preliminary data in patients with RRMM have been presented at the 2018 European Hematology Association (EHA)meeting in Stockholm (available online: http:/ / ehaweb.org).

Rao et al. [79] investigated the anti-angiogenic effect of MPO250, a multi-domain designed ankyrin repeat protein (DARPin) drug which binds simultaneously VEGF and HGF, in MM. They demonstrated that MPO250 reduces VEGFR-2 and cMET phosphorylation and affects their downstream signaling cascades. Moreover, MPO250 influences the secretory profile of MM endothelial cell, and inhibits in vitro and in vivo angiogenic activities of MM endothelial cells at higher extent than anti-VEGF or anti-HGF neutralizing monoclonal antibodies. Finally, in the syngeneic 5T33MM tumor model, MPO250 decreases the microvessel density and in combination with bortezomib, lowers the percentage of idiotype-positive cells and the serum levels of M protein.

Lamannuzzi et al. [80] evaluated mammalian target of rapamycin (mTOR) activation in endothelial cells from patients with MM and with MGUS. They demonstrated an increase of mTOR phosphorylation at the Ser2448 associated to a higher expression of RICTOR and to a rise in AKT phosphorylation at Ser473 in MM endothelial cells, indication that mTOR complex 2 (mTORC2) is more activated than mTORC1. On the contrary, MGUS endothelial cells showed an increase of SGK1 phosphorylation, expression of mTORC1 activation. These data were supported by the higher activation of mTORC2 downstream effectors, suggesting a major role of mTORC2 in the angiogenic switch to MM. Moreover, specific inhibition of mTOR activity through siRNA targeting RICTOR and dual mTOR inhibitor PP242 reduced the MM endothelial cells angiogenic functions, including cell migration, chemotaxis, adhesion, invasion, in vitro morphogenesis on Matrigel, and cytoskeleton reorganization. Finally, PP242 showed anti-angiogenic effects in vivo in the CAM and Matrigel plug assays, and exhibited a synergistic effect with lenalinomide and bortezomib.

\section{Concluding Remarks}

MM is the second most common blood-based malignancy, affecting approximately 20,000 new patients each year. More effective treatment options for MM are urgently needed. Disease relapse is inevitable and MM remains incurable. Anti-cancer drugs including novel therapies in monotherapy have debilitating side effects, and these treatments only benefit a minority of patients. The identification of subgroups of patients who will derive the most benefit from a drug with manageable drug-related toxicity is an important step towards improved response rates, safety and survival.

In addition to using anti-angiogenic agents that target more than one pro-angiogenic factor, another strategy is to use combined modalities. The abnormalities of the tumor vasculature and the impaired blood flow they cause result in an abnormal microenvironment that is characterized by hypertension, hypoxia and acidosis. These characteristics pose a significant barrier to cancer 
therapy, with leaky vessels impairing the delivery of therapeutics to the tumor and hypoxia rendering cells resistant to both radiation and many cytotoxic drugs. Therefore, an approach to normalize tumor vessels may correct the tumor microenvironment, making it more susceptible to therapy. Anti-angiogenic therapies have been shown to normalize tumor vasculature and can therefore improve treatment efficacy when co-administered with other therapies [81].

The median survival for patients with MM has almost doubled since the introduction of thalidomide, lenalidomide and bortezomib, along with autologous stem cell transplant [82]. Various combinations of thalidomide, lenalidomide and bortezomib, when combined with melphalan and prednisone or other drugs as first line therapies or in relapsed treatments have given higher overall response rates (ORRSs) and superior OS. However, most MM patients will still relapse and require a change in therapy [83]. In this context, treatment option is represented by monoclonal antibodies targeting CD38 (including Daratumab, Isatuximab, MOR202) and SLAMF7 [84,85]. In 2015, the anti-CD38 monoclonal antibody Daratumab has been approved by the US Food and Drug Administration (FDA), and a second anti-CD38 monoclonal antibody, Isatuximab, shows single-agent activity in patients with relapsed and refractory MM [86]. Clinical synergy with immunomodulatory agents has also been reported using SLAMF7 monoclonal antibody, Elotuzumab [87].

Resistance to anti-angiogenic agents is a clinically significant problem. Different approaches to circumvent this problem have been established, including the use of multiple-targeted anti-angiogenic agents and/or combined-modality treatment strategies. It would appear that the future of angiogenic inhibitors lies in the intelligent combination of multiple targeted agents with other angiogenic inhibitors to maximize therapeutic effect.

In conclusion, despite impressive performances in animal models, anti-angiogenic drugs are not performing nearly as well in humans. Anti-angiogenic treatments lead to a limited increase in PFS, followed by a relapse in tumor angiogenesis and growth. Further studies to optimize treatment regimens and to increase our understanding of tumor angiogenesis and the mechanisms underlying the development of resistance are required. The most important objective is to establish validated biomarkers with the aim to personalize treatments and select responding patient sub-populations.

Author Contributions: D.R. and A.V. equally contributed to the writing of this review article.

Funding: This work was supported by the Italian Association for Cancer Research (AIRC) through an Investigator Gran (No. 20441).

Conflicts of Interest: There are no conflicts of interest.

\section{Abbreviations}

$\mathrm{MM}$

$\mathrm{BM}$

PFS

OS

HSC

BMSCs

EPCs

VEGF/R

FGF-2/R

TNF- $\alpha$

HGF

IL-6 and IL-8

OPN

Ang-1

Tie-2/Tek

SDF1- $\alpha$ or CXCL12

MMPCs

MMECs multiple myeloma

bone marrow

progression free survival

overall survival

hematopoietic stem cell

bone marrow stromal cells

endothelial precursor cells

vascular endothelial growth factor/receptor

fibroblast growth factor-2/ receptor

tumor necrosis factor alpha

hepatocyte growth factor

interleukin-6 and -8

osteopontin

angiopoietin-1

angiopoietin-1 receptor

stromal cell-derived factor $1 \alpha$

multiple myeloma plasma cells

multiple myeloma ECs 


\begin{tabular}{|c|c|}
\hline HGF & hepatocyte growth factor \\
\hline c-Met & hepatocyte growth factor receptor \\
\hline Ang 1 & angiopoietin-1 \\
\hline Ang-2 & angiopoietin-2 \\
\hline IGF-1 & insulin-like growth factor-1 \\
\hline OPN & osteopontin \\
\hline MMP-2/9 & matrix metalloproteinases- $2 / 9$ \\
\hline PDGF-BB & platelet-derived growth factor-BB \\
\hline ADM & adrenomedullin \\
\hline TGF-1 & transforming growth factor-1 \\
\hline CXCL11/I-TAC & CXCL11-interferon-inducible T-cell chemoattractant \\
\hline MSCs & mesenchymal stem cells \\
\hline BNIP3 & BCL2 Interacting Protein 3 \\
\hline$B c l-2$ & B-cell lymphoma 2 \\
\hline IER3 & immediate early response 3 \\
\hline FAS & fas cell surface death receptor \\
\hline rHuEpo & recombinant human erythropoietin \\
\hline IMiDs & immounomodulatory drugs \\
\hline RRMM & refractory multiple myeloma \\
\hline ORR & higher overall response rate \\
\hline TTP & longer time to progression \\
\hline PFS & progression-free survival \\
\hline FVIIIRA & factor VIII-related antigen \\
\hline ERK & Extracellular signal-regulated kinases \\
\hline NFKB & nuclear factor kappa-light-chain-enhancer of activated B cells \\
\hline PDGF & platelet derived growth factor \\
\hline PDGFR $\beta$ & $\mathrm{BB} / \mathrm{PDGF}$ receptor beta \\
\hline AMD3100 & CXCR4 Antagonist \\
\hline SU11274 & cMET inhibitor \\
\hline DC101 & anti-murine VEGFR-2 antibody \\
\hline DARPin & multi-domain designed ankyrin repeat protein \\
\hline mTOR & mammalian target of rapamycin \\
\hline mTORC & mTOR complex \\
\hline CAM & chorioallantoic membrane \\
\hline
\end{tabular}

\section{References}

1. Ribatti, D.; Nico, B.; Crivellato, E.; Roccaro, A.M.; Vacca, A. The history of the angiogenic switch concept. Leukemia 2007, 21, 44-52. [CrossRef] [PubMed]

2. Vacca, A.; Ribatti, D.; Roncali, L.; Ranieri, G.; Serio, G.; Silvestris, F.; Dammacco, F. Bone marrow angiogenesis and progression in multiple myeloma. Br. J. Haematol. 1994, 87, 503-508. [CrossRef] [PubMed]

3. Ribatti, D. The discovery of endothelial progenitor cells. Leuk. Res. 2007, 31, 439-444. [CrossRef] [PubMed]

4. Maniotis, A.J.; Folberg, R.; Hess, A.; Seftor, E.A.; Gardner, L.M.G.; Pe'er, J.; Trent, J.M.; Meltzer, P.S.; Hendrix, M.J.C. Vascular channel formation by human melanoma cells in vivo and in vitro: Vasculogenic mimicry. Am. J. Pathol. 1999, 155, 739-752. [CrossRef]

5. Holash, J. Vessel cooption regression, and growth in tumors mediated by angiopoietins and VEGF. Science 1999, 284, 1994-1998. [CrossRef] [PubMed]

6. Ribatti, D.; Djonov, V. Intussusceptive microvascular growth in tumors. Cancer Lett. 2012, 316, $126-131$. [CrossRef] [PubMed]

7. Vacca, A.; Ribatti, D. Bone marrow angiogenesis in multiple myeloma. Leukemia 2005, 20, 193-199. [CrossRef] [PubMed]

8. Vacca, A.; Ribatti, D.; Presta, M.; Minischetti, M.; Iurlaro, M.; Ria, R.; Albini, A.; Bussolino, F.; Dammacco, F. Bone marrow neovascularization, plasma cell angiogenic potential, and matrix metalloproteinase-2 secretion parallel progression of human multiple myeloma. Blood 1999, 93, 3064-3073. [PubMed] 
9. Hose, D.; Moreaux, J.; Meissner, T.; Seckinger, A.; Goldschmidt, H.; Benner, A.; Mahtouk, K.; Hillengass, J.; Reme, T.; De Vos, J.; et al. Induction of angiogenesis by normal and malignant plasma cells. Blood 2009, 114, 128-143. [CrossRef] [PubMed]

10. Rajkumar, S.V.; Mesa, R.A.; Fonseca, R.; Schroeder, G.; Plevak, M.F.; Dispenzieri, A.; Lacy, M.Q.; Lust, J.A.; Witzig, T.E.; Gertz, M.A.; et al. Bone marrow angiogenesis in 400 patients with monoclonal gammopathy of undetermined significance, multiple myeloma, and primary amyloidosis. Clin. Cancer Res. 2002, 8, 2210-2216. [PubMed]

11. Jakob, C.; Sterz, J.; Zavrski, I.; Heider, U.; Kleeberg, L.; Fleissner, C.; Kaiser, M.; Sezer, O. Angiogenesis in multiple myeloma. Eur. J. Cancer 2006, 42, 1581-1590. [CrossRef] [PubMed]

12. Kumar, S. Bone marrow angiogenic ability and expression of angiogenic cytokines in myeloma: Evidence favoring loss of marrow angiogenesis inhibitory activity with disease progression. Blood 2004, 104, 1159-1165. [CrossRef] [PubMed]

13. Ribatti, D.; Nico, B.; Vacca, A. Importance of the bone marrow microenvironment in inducing the angiogenic response in multiple myeloma. Oncogene 2006, 25, 4257-4266. [CrossRef] [PubMed]

14. Ribatti, D.; Vacca, A. The role of monocytes-macrophages in vasculogenesis in multiple myeloma. Leukemia 2009, 23, 1535-1536. [CrossRef] [PubMed]

15. Frassanito, M.A.; Rao, L.; Moschetta, M.; Ria, R.; Di Marzo, L.; De Luisi, A.; Racanelli, V.; Catacchio, I.; Berardi, S.; Basile, A.; et al. Bone marrow fibroblasts parallel multiple myeloma progression in patients and mice: In vitro and in vivo studies. Leukemia 2013, 28, 904-916. [CrossRef] [PubMed]

16. Nico, B.; Mangieri, D.; Crivellato, E.; Vacca, A.; Ribatti, D. Mast cells contribute to vasculogenic mimicry in multiple myeloma. Stem Cells Dev. 2008, 17, 19-22. [CrossRef] [PubMed]

17. Scavelli, C.; Nico, B.; Cirulli, T.; Ria, R.; Di Pietro, G.; Mangieri, D.; Bacigalupo, A.; Mangialardi, G.; Coluccia, A.M.L.; Caravita, T.; et al. Vasculogenic mimicry by bone marrow macrophages in patients with multiple myeloma. Oncogene 2007, 27, 663-674. [CrossRef] [PubMed]

18. Ribatti, D.; Vacca, A. Multiple myeloma bone marrow angiogenesis. In Multiple Myeloma. A New Era of Treatment Strategies; Podar, K., Anderson, K.C., Eds.; Bentham Science Publishers: Sharjah, United Arab Emirates, 2012; pp. 138-148.

19. Zheng, Y.; Cai, Z.; Wang, S.; Zhang, X.; Qian, J.; Hong, S.; Li, H.; Wang, M.; Yang, J.; Yi, Q. Macrophages are an abundant component of myeloma microenvironment and protect myeloma cells from chemotherapy drug-induced apoptosis. Blood 2009, 114, 3625-3628. [CrossRef] [PubMed]

20. Ribatti, D.; Vacca, A.; Nico, B.; Quondamatteo, F.; Ria, R.; Minischetti, M.; Marzullo, A.; Herken, R.; Roncali, L.; Dammacco, F. Bone marrow angiogenesis and mast cell density increase simultaneously with progression of human multiple myeloma. Br. J. Cancer 1999, 79, 451-455. [CrossRef] [PubMed]

21. Ria, R.; Piccoli, C.; Cirulli, T.; Falzetti, F.; Mangialardi, G.; Guidolin, D.; Tabilio, A.; Di Renzo, N.; Guarini, A.; Ribatti, D.; et al. Endothelial differentiation of hematopoietic stem and progenitor cells from patients with multiple myeloma. Clin. Cancer Res. 2008, 14, 1678-1685. [CrossRef] [PubMed]

22. Ribatti, D.; Nico, B.; Vacca, A. Multiple myeloma as a model for the role of bone marrow niches in the control of angiogenesis. Int. Rev. Cell Mol. Biol. 2015, 314, 259-282. [PubMed]

23. Ria, R.; Todoerti, K.; Berardi, S.; Coluccia, A.M.L.; De Luisi, A.; Mattioli, M.; Ronchetti, D.; Morabito, F.; Guarini, A.; Petrucci, M.T.; et al. Gene expression profiling of bone marrow endothelial cells in patients with multiple myeloma. Clin. Cancer Res. 2009, 15, 5369-5378. [CrossRef] [PubMed]

24. De Luisi, A.; Binetti, L.; Ria, R.; Ruggieri, S.; Berardi, S.; Catacchio, I.; Racanelli, V.; Pavone, V.; Rossini, B.; Vacca, A.; et al. Erythropoietin is involved in the angiogenic potential of bone marrow macrophages in multiple myeloma. Angiogenesis 2013, 16, 963-973. [CrossRef] [PubMed]

25. Lamanuzzi, A.; Saltarella, I.; Ferrucci, A.; Ria, R.; Ruggieri, S.; Racanelli, V.; Rao, L.; Annese, T.; Nico, B.; Vacca, A.; et al. Role of erythropoietin in the angiogenic activity of bone marrow endothelial cells of MGUS and multiple myeloma patients. Oncotarget 2016, 7, 14510-14521. [CrossRef] [PubMed]

26. Mangieri, D.; Nico, B.; Benagiano, V.; De Giorgis, M.; Vacca, A.; Ribatti, D. Angiogenic activity of multiple myeloma endothelial cells in vivo in the chick embryo chorioallantoic membrane assay is associated to a down-regulation in the expression of endogenous endostatin. J. Cell Mol. Med. 2008, 12, 1023-1028. [CrossRef] [PubMed]

27. Ribatti, D.; Vacca, A. Therapeutic renaissance of thalidomide in the treatment of haematological malignancies. Leukemia 2005, 19, 1525-1531. [CrossRef] [PubMed] 
28. Vacca, A.; Scavelli, C.; Montefusco, V.; Di Pietro, G.; Neri, A.; Mattioli, M.; Bicciato, S.; Nico, B.; Ribatti, D.; Dammacco, F.; et al. Thalidomide downregulates angiogenic genes in bone marrow endothelial cells of patients with active multiple myeloma. J. Clin. Oncol. 2005, 23, 5334-5346. [CrossRef] [PubMed]

29. Davies, F.E. Thalidomide and immunomodulatory derivatives augment natural killer cell cytotoxicity in multiple myeloma. Blood 2001, 98, 210-216. [CrossRef] [PubMed]

30. Mitsiades, N. Apoptotic signaling induced by immunomodulatory thalidomide analogs in human multiple myeloma cells: Therapeutic implications. Blood 2002, 99, 4525-4530. [CrossRef] [PubMed]

31. Singhal, S.; Mehta, J.; Desikan, R.; Ayers, D.; Roberson, P.; Eddlemon, P.; Munshi, N.; Anaissie, E.; Wilson, C.; Dhodapkar, M.; et al. Antitumor activity of thalidomide in refractory multiple myeloma. N. Engl. J. Med. 1999, 341, 1565-1571. [CrossRef] [PubMed]

32. Lu, L.; Payvandi, F.; Wu, L.; Zhang, L.-H.; Hariri, R.J.; Man, H.-W.; Chen, R.S.; Muller, G.W.; Hughes, C.C.W.; Stirling, D.I.; et al. The anti-cancer drug lenalidomide inhibits angiogenesis and metastasis via multiple inhibitory effects on endothelial cell function in normoxic and hypoxic conditions. Microvasc. Res. 2009, 77, 78-86. [CrossRef] [PubMed]

33. Chang, D.H. Enhancement of ligand-dependent activation of human natural killer T cells by lenalidomide: Therapeutic implications. Blood 2006, 108, 618-621. [CrossRef] [PubMed]

34. Dredge, K.; Horsfall, R.; Robinson, S.P.; Zhang, L.-H.; Lu, L.; Tang, Y.; Shirley, M.A.; Muller, G.; Schafer, P.; Stirling, D.; et al. Orally administered lenalidomide (CC-5013) is anti-angiogenic in vivo and inhibits endothelial cell migration and Akt phosphorylation in vitro. Microvasc. Res. 2005, 69, 56-63. [CrossRef] [PubMed]

35. Gorgun, G.; Calabrese, E.; Soydan, E.; Hideshima, T.; Perrone, G.; Bandi, M.; Cirstea, D.; Santo, L.; Hu, Y.; Tai, Y.T.; et al. Immunomodulatory effects of lenalidomide and pomalidomide on interaction of tumor and bone marrow accessory cells in multiple myeloma. Blood 2010, 116, 3227-3237. [CrossRef] [PubMed]

36. Hideshima, T.; Mitsiades, C.; Tonon, G.; Richardson, P.G.; Anderson, K.C. Understanding multiple myeloma pathogenesis in the bone marrow to identify new therapeutic targets. Nature Reviews Cancer 2007, 7, 585-598. [CrossRef] [PubMed]

37. Anderson, G. Thalidomide derivative CC-4047 inhibits osteoclast formation by down-regulation of PU.1. Blood 2006, 107, 3098-3105. [CrossRef] [PubMed]

38. Breitkreutz, I.; Raab, M.S.; Vallet, S.; Hideshima, T.; Raje, N.; Mitsiades, C.; Chauhan, D.; Okawa, Y.; Munshi, N.C.; Richardson, P.G.; et al. Lenalidomide inhibits osteoclastogenesis, survival factors and bone-remodeling markers in multiple myeloma. Leukemia 2008, 22, 1925-1932. [CrossRef] [PubMed]

39. De Luisi, A.; Ferrucci, A.; Coluccia, A.M.L.; Ria, R.; Moschetta, M.; de Luca, E.; Pieroni, L.; Maffia, M.; Urbani, A.; Di Pietro, G.; et al. Lenalidomide restrains motility and overangiogenic potential of bone marrow endothelial cells in patients with active multiple myeloma. Clin. Cancer Res. 2011, 17, 1935-1946. [CrossRef] [PubMed]

40. Cibeira, M.T.; Rozman, M.; Segarra, M.; Lozano, E.; Rosiñol, L.; Cid, M.C.; Filella, X.; Bladé, J. Bone marrow angiogenesis and angiogenic factors in multiple myeloma treated with novel agents. Cytokine 2008, 41, 244-253. [CrossRef] [PubMed]

41. Richardson, P.G.; Blood, E.; Mitsiades, C.S.; Jagannath, S.; Zeldenrust, S.R.; Alsina, M.; Schlossman, R.L.; Rajkumar, S.V.; Desikan, K.R.; Hideshima, T.; et al. A randomized phase 2 study of lenalidomide therapy for patients with relapsed or relapsed and refractory multiple myeloma. Blood 2006, 108, 3458-3464. [CrossRef] [PubMed]

42. Rajkumar, S.V. Combination therapy with lenalidomide plus dexamethasone (Rev/Dex) for newly diagnosed myeloma. Blood 2005, 106, 4050-4053. [CrossRef] [PubMed]

43. Wang, M.; Dimopoulos, M.A.; Chen, C.; Cibeira, M.T.; Attal, M.; Spencer, A.; Rajkumar, S.V.; Yu, Z.; Olesnyckyj, M.; Zeldis, J.B.; et al. Lenalidomide plus dexamethasone is more effective than dexamethasone alone in patients with relapsed or refractory multiple myeloma regardless of prior thalidomide exposure. Blood 2008, 112, 4445-4451. [CrossRef] [PubMed]

44. Kastritis, E.; Palumbo, A.; Dimopoulos, M.A. Treatment of relapsed/refractory multiple myeloma. Semin. Hematol. 2009, 46, 143-157. [CrossRef] [PubMed]

45. Dimopoulos, M.A.; Kastritis, E.; Christoulas, D.; Migkou, M.; Gavriatopoulou, M.; Gkotzamanidou, M.; Iakovaki, M.; Matsouka, C.; Mparmparoussi, D.; Roussou, M.; et al. Treatment of patients with relapsed/refractory multiple myeloma with lenalidomide and dexamethasone with or without bortezomib: 
Prospective evaluation of the impact of cytogenetic abnormalities and of previous therapies. Leukemia 2010, 24, 1769-1778. [CrossRef] [PubMed]

46. Barosi, G.; Merlini, G.; Billio, A.; Boccadoro, M.; Corradini, P.; Marchetti, M.; Massaia, M.; Tosi, P.; Palumbo, A.; Cavo, M.; et al. SIE, SIES, GITMO evidence-based guidelines on novel agents (thalidomide, bortezomib, and lenalidomide) in the treatment of multiple myeloma. Ann. Hematol. 2012, 91, 875-888. [CrossRef] [PubMed]

47. Chanan-Khan, A.A.; Swaika, A.; Paulus, A.; Kumar, S.K.; Mikhael, J.R.; Rajkumar, S.V.; Dispenzieri, A.; Lacy, M.Q. Pomalidomide: The new immunomodulatory agent for the treatment of multiple myeloma. Blood Cancer J. 2013, 3, e143-e143. [CrossRef] [PubMed]

48. Schey, S.A.; Fields, P.; Bartlett, J.B.; Clarke, I.A.; Ashan, G.; Knight, R.D.; Streetly, M.; Dalgleish, A.G. Phase I study of an immunomodulatory thalidomide analog, CC-4047, in relapsed or refractory multiple myeloma. J. Clin. Oncol. 2004, 22, 3269-3276. [CrossRef] [PubMed]

49. Streetly, M.J.; Gyertson, K.; Daniel, Y.; Zeldis, J.B.; Kazmi, M.; Schey, S.A. Alternate day pomalidomide retains anti-myeloma effect with reduced adverse events and evidence of in vivo immunomodulation. Br. J. Haematol. 2008, 141, 41-51. [CrossRef] [PubMed]

50. Lacy, M.Q.; Allred, J.B.; Gertz, M.A.; Hayman, S.R.; Short, K.D.; Buadi, F.; Dispenzieri, A.; Kumar, S.; Greipp, P.R.; Lust, J.A.; et al. Pomalidomide plus low-dose dexamethasone in myeloma refractory to both bortezomib and lenalidomide: Comparison of 2 dosing strategies in dual-refractory disease. Blood 2011, 118, 2970-2975. [CrossRef] [PubMed]

51. Lacy, M.Q.; Hayman, S.R.; Gertz, M.A.; Dispenzieri, A.; Buadi, F.; Kumar, S.; Greipp, P.R.; Lust, J.A.; Russell, S.J.; Dingli, D.; et al. Pomalidomide (CC4047) Plus Low-Dose Dexamethasone As Therapy for Relapsed Multiple Myeloma. J. Clin. Oncol. 2009, 27, 5008-5014. [CrossRef] [PubMed]

52. Lacy, M.Q.; Hayman, S.R.; Gertz, M.A.; Short, K.D.; Dispenzieri, A.; Kumar, S.; Greipp, P.R.; Lust, J.A.; Russell, S.J.; Dingli, D.; et al. Pomalidomide (CC4047) plus low dose dexamethasone (Pom/dex) is active and well tolerated in lenalidomide refractory multiple myeloma (MM). Leukemia 2010, 24, 1934-1939. [CrossRef] [PubMed]

53. Miguel, J.S.; Weisel, K.; Moreau, P.; Lacy, M.; Song, K.; Delforge, M.; Karlin, L.; Goldschmidt, H.; Banos, A.; Oriol, A.; et al. Pomalidomide plus low-dose dexamethasone versus high-dose dexamethasone alone for patients with relapsed and refractory multiple myeloma (MM-003): A randomised, open-label, phase 3 trial. Lancet Oncol. 2013, 14, 1055-1066. [CrossRef]

54. Williams, S.; Pettaway, C.; Song, R.; Papandreou, C.; Logothetis, C.; McConkey, D.J. Differential effects of the proteasome inhibitor bortezomib on apoptosis and angiogenesis in human prostate tumor xenografts. Mol. Cancer Ther. 2003, 2, 835-843. [PubMed]

55. Hideshima, T.; Chauhan, D.; Hayashi, T.; Akiyama, M.; Mitsiades, N.; Mitsiades, C.; Podar, K.; Munshi, N.C.; Richardson, P.G.; Anderson, K.C. Proteasome inhibitor PS-341 abrogates IL-6 triggered signaling cascades via caspase-dependent downregulation of gp130 in multiple myeloma. Oncogene 2003, 22, 8386-8393. [CrossRef] [PubMed]

56. Roccaro, A.M.; Hideshima, T.; Raje, N.; Kumar, S.; Ishitsuka, K.; Yasui, H.; Shiraishi, N.; Ribatti, D.; Nico, B.; Vacca, A.; et al. Bortezomib mediates antiangiogenesis in multiple myeloma via direct and indirect effects on endothelial cells. Cancer Res. 2006, 66, 184-191. [CrossRef] [PubMed]

57. Field-Smith, A.; Morgan, G.J.; Davies, F.E. Bortezomib (Velcadetrade mark) in the Treatment of Multiple Myeloma. Ther. Clin. Risk Manag. 2006, 2, 271-279. [CrossRef] [PubMed]

58. Ziogas, D.C.; Terpos, E.; Kastritis, E.; Dimopoulos, M.A. An overview of the role of carfilzomib in the treatment of multiple myeloma. Expert Opin. Pharmacother. 2017, 18, 1883-1897. [CrossRef] [PubMed]

59. Demo, S.D.; Kirk, C.J.; Aujay, M.A.; Buchholz, T.J.; Dajee, M.; Ho, M.N.; Jiang, J.; Laidig, G.J.; Lewis, E.R.; Parlati, F.; et al. Antitumor activity of PR-171, a novel irreversible inhibitor of the proteasome. Cancer Res. 2007, 67, 6383-6391. [CrossRef] [PubMed]

60. Kuhn, D.J.; Chen, Q.; Voorhees, P.M.; Strader, J.S.; Shenk, K.D.; Sun, C.M.; Demo, S.D.; Bennett, M.K.; van Leeuwen, F.W.; Chanan-Khan, A.A.; et al. Potent activity of carfilzomib, a novel, irreversible inhibitor of the ubiquitin-proteasome pathway, against preclinical models of multiple myeloma. Blood 2007, 110, 3281-3290. [CrossRef] [PubMed]

61. Scavelli, C.; Di Pietro, G.; Cirulli, T.; Coluccia, M.; Boccarelli, A.; Giannini, T.; Mangialardi, G.; Bertieri, R.; Coluccia, A.M.L.; Ribatti, D.; et al. Zoledronic acid affects over-angiogenic phenotype of endothelial cells in patients with multiple myeloma. Mol. Cancer Ther. 2007, 6, 3256-3262. [CrossRef] [PubMed] 
62. Moschetta, M.; Di Pietro, G.; Ria, R.; Gnoni, A.; Mangialardi, G.; Guarini, A.; Ditonno, P.; Musto, P.; D'Auria, F.; Ricciardi, M.R.; et al. Bortezomib and zoledronic acid on angiogenic and vasculogenic activities of bone marrow macrophages in patients with multiple myeloma. Eur. J. Cancer 2010, 46, 420-429. [CrossRef] [PubMed]

63. Kim, J.; Denu, R.A.; Dollar, B.A.; Escalante, L.E.; Kuether, J.P.; Callander, N.S.; Asimakopoulos, F.; Hematti, P. Macrophages and mesenchymal stromal cells support survival and proliferation of multiple myeloma cells. Br. J. Haematol. 2012, 158, 336-346. [CrossRef] [PubMed]

64. Podar, K.; Tonon, G.; Sattler, M.; Tai, Y.T.; LeGouill, S.; Yasui, H.; Ishitsuka, K.; Kumar, S.; Kumar, R.; Pandite, L.N.; et al. The small-molecule VEGF receptor inhibitor pazopanib (GW786034B) targets both tumor and endothelial cells in multiple myeloma. Proc. Natl. Acad. Sci. USA 2006, 103, 19478-19483. [CrossRef] [PubMed]

65. Prince, H.M.; Hönemann, D.; Spencer, A.; Rizzieri, D.A.; Stadtmauer, E.A.; Roberts, A.W.; Bahlis, N.; Tricot, G.; Bell, B.; DeMarini, D.J.; et al. Vascular endothelial growth factor inhibition is not an effective therapeutic strategy for relapsed or refractory multiple myeloma: A phase 2 study of pazopanib (GW786034): Table 1. Blood 2009, 113, 4819-4820. [CrossRef] [PubMed]

66. Airoldi, I.; Cocco, C.; Giuliani, N.; Ferrarini, M.; Colla, S.; Ognio, E.; Taverniti, G.; Di Carlo, E.; Cutrona, G.; Perfetti, V.; et al. Constitutive expression of IL-12R beta 2 on human multiple myeloma cells delineates a novel therapeutic target. Blood 2008, 112, 750-759. [CrossRef] [PubMed]

67. Coluccia, A.M.L.; Cirulli, T.; Neri, P.; Mangieri, D.; Colanardi, M.C.; Gnoni, A.; Di Renzo, N.; Dammacco, F.; Tassone, P.; Ribatti, D.; et al. Validation of PDGFR and c-Src tyrosine kinases as tumor/vessel targets in patients with multiple myeloma: Preclinical efficacy of the novel, orally available inhibitor dasatinib. Blood 2008, 112, 1346-1356. [CrossRef] [PubMed]

68. Roccaro, A.M.; Sacco, A.; Thompson, B.; Leleu, X.; Azab, A.K.; Azab, F.; Runnels, J.; Jia, X.; Ngo, H.T.; Melhem, M.R.; et al. MicroRNAs 15a and 16 regulate tumor proliferation in multiple myeloma. Blood 2009, 113, 6669-6680. [CrossRef] [PubMed]

69. Azab, A.K.; Roccaro, A.M.; Runnels, J.; Sacco, A.; Burwick, N.; Azab, F.; Pitsillides, C.; Ngo, H.T.; Jia, X.; Melhem, M.R.; et al. B622 Rho-A and Rac-1 GTPases in multiple myeloma. Clin. Lymphoma Myeloma 2009, 9, S159. [CrossRef]

70. Roccaro, A.M.; Mishima, Y.; Sacco, A.; Moschetta, M.; Tai, Y.-T.; Shi, J.; Zhang, Y.; Reagan, M.R.; Huynh, D.; Kawano, Y.; et al. CXCR4 regulates extra-medullary myeloma through epithelial-mesenchymal-transition-like transcriptional activation. Cell Rep. 2015, 12, 622-635. [CrossRef] [PubMed]

71. Ramakrishnan, V.; Timm, M.; Haug, J.L.; Kimlinger, T.K.; Wellik, L.E.; Witzig, T.E.; Rajkumar, S.V.; Adjei, A.A.; Kumar, S. Sorafenib, a dual Raf kinase/vascular endothelial growth factor receptor inhibitor has significant anti-myeloma activity and synergizes with common anti-myeloma drugs. Oncogene 2009, 29, 1190-1202. [CrossRef] [PubMed]

72. Yordanova, A.; Hose, D.; Neben, K.; Witzens-Harig, M.; Gutgemann, I.; Raab, M.S.; Moehler, T.; Goldschmidt, H.; Schmidt-Wolf, I.G. Sorafenib in patients with refractory or recurrent multiple myeloma. Hematol. Oncol. 2013, 31, 197-200. [CrossRef] [PubMed]

73. Podar, K.; Zimmerhackl, A.; Fulciniti, M.; Tonon, G.; Hainz, U.; Tai, Y.-T.; Vallet, S.; Halama, N.; Jäger, D.; Olson, D.L.; et al. The selective adhesion molecule inhibitor Natalizumab decreases multiple myeloma cell growth in the bone marrow microenvironment: Therapeutic implications. Br. J. Haematol. 2011, 155, 438-448. [CrossRef] [PubMed]

74. Mimura, N.; Hideshima, T.; Shimomura, T.; Suzuki, R.; Ohguchi, H.; Rizq, O.; Kikuchi, S.; Yoshida, Y.; Cottini, F.; Jakubikova, J.; et al. Selective and potent Akt inhibition triggers anti-myeloma activities and enhances fatal endoplasmic reticulum stress induced by proteasome inhibition. Cancer Res. 2014, 74, 4458-4469. [CrossRef] [PubMed]

75. Ferrucci, A.; Moschetta, M.; Frassanito, M.A.; Berardi, S.; Catacchio, I.; Ria, R.; Racanelli, V.; Caivano, A.; Solimando, A.G.; Vergara, D.; et al. A HGF/cMET autocrine loop is operative in multiple myeloma bone marrow endothelial cells and may represent a novel therapeutic target. Clin. Cancer Res. 2014, 20, 5796-5807. [CrossRef] [PubMed]

76. Moschetta, M.; Basile, A.; Ferrucci, A.; Frassanito, M.A.; Rao, L.; Ria, R.; Solimando, A.G.; Giuliani, N.; Boccarelli, A.; Fumarola, F.; et al. Novel targeting of phospho-cMET overcomes drug resistance and induces antitumor activity in multiple myeloma. Clin. Cancer Res. 2013, 19, 4371-4382. [CrossRef] [PubMed] 
77. Umezu, T.; Imanishi, S.; Azuma, K.; Kobayashi, C.; Yoshizawa, S.; Ohyashiki, K.; Ohyashiki, J.H. Replenishing exosomes from older bone marrow stromal cells with miR-340 inhibits myeloma-related angiogenesis. Blood Adv. 2017, 1, 812-823. [CrossRef] [PubMed]

78. Moschetta, M.; Mishima, Y.; Kawano, Y.; Manier, S.; Paiva, B.; Palomera, L.; Aljawai, Y.; Calcinotto, A.; Unitt, C.; Sahin, I.; et al. Targeting vasculogenesis to prevent progression in multiple myeloma. Leukemia 2016, 30, 1103-1115. [CrossRef] [PubMed]

79. Rao, L.; De Veirman, K.; Giannico, D.; Saltarella, I.; Desantis, V.; Frassanito, M.A.; Solimando, A.G.; Ribatti, D.; Prete, M.; Harstrick, A.; et al. Targeting angiogenesis in multiple myeloma by the VEGF and HGF blocking DARPin ${ }^{\circledR}$ protein MP0250: A preclinical study. Oncotarget 2018, 9, 13366-13381. [CrossRef] [PubMed]

80. Lamanuzzi, A.; Saltarella, I.; Desantis, V.; Frassanito, M.A.; Leone, P.; Racanelli, V.; Nico, B.; Ribatti, D.; Ditonno, P.; Prete, M.; et al. Inhibition of mTOR complex 2 restrains tumor angiogenesis in multiple myeloma. Oncotarget 2018, 9, 20563-20577. [CrossRef] [PubMed]

81. Jain, R.K. Normalization of tumor vasculature: An emerging concept in antiangiogenic therapy. Science 2005, 307, 58-62. [CrossRef] [PubMed]

82. Anderson, K.C. The 39th David A. Karnofsky Lecture: Bench-to-Bedside Translation of Targeted Therapies in multiple myeloma. J. Clin. Oncol. 2012, 30, 445-452. [CrossRef] [PubMed]

83. Orlowski, R.Z.; Lonial, S. Integration of novel agents into the care of patients with multiple myeloma. Clin. Cancer Res. 2016, 22, 5443-5452. [CrossRef] [PubMed]

84. Kumar, S.K.; Anderson, K.C. Immune therapies in multiple myeloma. Clin. Cancer Res. 2016, 22, 5453-5460. [CrossRef] [PubMed]

85. Lonial, S. Monoclonal antibodies for the treatment of myeloma. Cancer J. 2016, 22, 3-6. [CrossRef] [PubMed]

86. Vij, R.; Lendvai, N.; Martin, T.G.; Baz, R.C.; Campana, F.; Mazuir, F.; Charpentier, E.; Benson, D.M. A phase Ib dose escalation trial of isatuximab (SAR650984, anti-CD38 mAb) plus lenalidomide and dexamethasone (Len/Dex) in relapsed/refractory multiple myeloma (RRMM): Interim results from two new dose cohorts. J. Clin. Oncol. 2016, 34 (Suppl. 15), S8009.

87. Lonial, S.; Dimopoulos, M.; Palumbo, A.; White, D.; Grosicki, S.; Spicka, I.; Walter-Croneck, A.; Moreau, P.; Mateos, M.V.; Magen, H.; et al. Elotuzumab therapy for relapsed or refractory multiple myeloma. N. Engl. J. Med. 2015, 373, 621-631. [CrossRef] [PubMed] 